DOI 10.31558/2307-2318.2018.3.6

УДК 338.242.2:378.1

Біленко Д. В., к.е.н., доцент кафедри бізнес-статистики та економічної кібернетики Донецький національний університет імені Василя Стуса

\title{
ОСОБЛИВОСТІ ВПРОВАДЖЕННЯ МАРКЕТИНГОВИХ ЗАХОДІВ В СФЕРІ ОСВІТНІХ ПОСЛУГ
}

В статті проведено аналіз теоретичної бази та результатів досліджень ефективного управління ВНЗ на практиці, розглянуто основні проблеми сучасної вищої освіти в Україні, доведено необхідність визначення основних особливостей впровадження маркетингових заходів в сфері освітніх послуг, на підставі яких в подальшому буде запропоновано цілісну маркетингову стратегію. Перша особливість, яку необхідно враховувати при впровадженні маркетингових заходів в сфері освітніх послуг, полягає в тому, що в більшості випадків особа, що приймає рішення про вибір ВНЗ для вступу, не $є$ споживачем освітньої послуги. Тобто цільовою аудиторією виступає не тільки абітурієнт, але і його батьки, і мотиви, які спонукають до вступу, повинні задовольняти обох. Друга особливість полягає в тому, що традиційні способи реклами не тільки неефективні, але і знижують «цінність» ВНЗ в очах споживача. Останньою особливістю виступає те, що задовольняючи критеріям абітурієнта як майбутнього споживача освітніх послуг, ВНЗ може відмовити йому в їх наданні. Якщо враховувати кожну з зазначених особливостей окремо, то інструментів для ефективних маркетингових заходів - достатня кількість. Якщо ж розглядати їх в сукупності, то, в умовах перевищення пропозиції над попитом зниження вимог до абітурієнтів призведе до великого щорічного набору, але зменшить число позитивних інформаційних повідомлень про рівень підготовки у ВНЗ. Отримане протиріччя вимагає розробки і впровадження маркетингової стратегії, заходи якої задовольняли 6 кожній 3 розглянутих особливостей в комплексі.

Ключові слова: впровадження маркетингових заходів, маркетингова стратегія BH3.

Беленко Д.В.

\section{ОСОБЕННОСТИ ВНЕДРЕНИЯ МАРКЕТИНГОВЫХ МЕРОПРИЯТИЙ В СФЕРЕ ОБРАЗОВАТЕЛЬНЫХ УСЛУГ}

В статье проведен анализ теоретической базы и результатов исследований эффективного управления ВУЗом на практике, рассмотрены основные проблемы современного высшего образования в Украине, доказана необходимость определения основных особенностей внедрения маркетинговых мероприятий в сфере образовательных услуг, на основании которых в дальнейшем будет предложена целостная маркетинговая стратегия. Первая особенность, которую необходимо учитывать при внедрении маркетинговых мероприятий в сфере образовательных услуг, заключается в том, что в большинстве случаев лицо, принимающее решение о выборе ВУЗа для поступления, не является потребителем образовательной услуги. То есть целевой аудиторией выступает не только абитуриент, но и его родители, и мотивы, побуждающие к поступлению, должны удовлетворять обоих. Вторая особенность заключается в том, что традиционные способы рекламы не только неэффективны, но и снижают «ценность» ВУЗов в глазах потребителя. Последней особенностью выступает то, что, удовлетворяя критериям абитуриента как будущего потребителя образовательных услуг, ВУЗ может отказать ему в их предоставлении. Если учитывать каждую из указанных особенностей отдельно, то инструментов для эффективных 
маркетинговых мероприятий - достаточное количество. Если же рассматривать их в совокупности, то, в условиях превышения предложения над спросом снижение требований к абитуриентам приведет к большему ежегодному набору, но уменьшит число положительных информационных сообщений об уровне подготовки в ВУЗе. Полученное противоречие требует разработки и внедрения маркетинговой стратегии, которая удовлетворяла бы каждому из рассмотренных особенностей в комплексе.

Ключевые слова: внедрение маркетинговых мероприятий, маркетинговая стратегия ВУЗа.

\section{Bilenko D. V. \\ FEATURES OF THE MARKETING ACTIVITIES IMPLEMENTATION IN THE EDUCATION}

The article analyzes the theoretical base and research results of effective university management in practice, discusses the main problems of modern higher education in Ukraine, proves the need to identify the main features of the marketing activities implementation in the education, based on which a complete marketing strategy will be proposed. The first feature that should be considered when introducing marketing activities in the education is that in most cases the decision-making person is not a consumer of the educational service. That is, the target audience is not only the applicant, but also his parents, and the motives must satisfy both. The second feature is that traditional methods of advertising are not only ineffective, but also reduce the "value" of universities in the consumer's eyes. The last feature is the fact that, satisfying the criteria of the applicant as a future consumer of educational services, the university can refuse to provide them. If we consider each of these features separately, then there are enough tools for effective marketing activities. If we consider them in aggregate, then, in the conditions of excess of supply over demand, the reduction in requirements for applicants will lead to a larger annual recruitment but will reduce the number of positive informational messages about the training level at the university. The resulting contradiction requires the development and marketing strategy implementation that would satisfy each of the considered features in the complex.

Keywords: marketing activities implementation, the university marketing strategy.

Постановка проблеми та її зв'язок 3 важливими науковими та практичними завданнями. Освіта як цілеспрямований процес виховання та навчання в інтересах людини, суспільства, держави, в першу чергу, обумовлюється вимогами виробництва, станом науки, техніки і культури, а також суспільними відносинами. В Україні, як і в усьому світі, процес здобуття освіти можна розглядати як товар або послугу нематеріального характеру, що надається відповідними установами. Після переходу до ринкової економіки в Україні почав формуватися ринок освітніх послуг, який склався менш ніж за 20 років: кількість ВНЗ III-IV рівня акредитації з 1990 по 2017 рр. збільшилася з 149 до 289 штук, тобто майже в 2 рази, також як і чисельність студентів в них (з 881,3 до 1330,0 тис. осіб) [1]. При цьому приріст населення в Україні з 1991 року - негативний, а чисельність молодих людей до 17 років зменшилася на 40\% [2]. Звідси можна бачити тенденцію до перевищення пропозиції над попитом. Вирішення цієї проблеми шляхом проведення профорієнтаційної роботи зі школярами виявилося неефективним. Як показують дослідження, стимулами для вибору ВНЗ у більшості українських школярів є вибір батьків, обумовлений або майбутніми очікуваннями від отриманої професії, або можливістю вступу в даний ВНЗ. 
Незважаючи на існуючі методи просування освітніх послуг, що позитивно себе зарекомендували, широко застосовуння на ринку українських освітніх послуг вони не знайшли, що можна пояснити тим, що на протязі 70 років радянського режиму в умовах державного замовлення необхідності у використанні маркетингових заходів в сфері освітніх послуг не було. Відповідно сьогодні для успішного конкурування, як на внутрішньому, так і на світовому ринках, українським ВНЗ необхідно впроваджувати в свою практику маркетингові інструменти управління.

Аналіз останніх досліджень і публікацій 3 проблеми, що розглядасться. Проблема застосування маркетингу в галузі освіти викликає інтерес як теоретиків вчених-економістів, так і практиків - керівників ВНЗ. Дослідженням проблеми ефективності маркетингу освітніх послуг присвячені праці сучасних вчених: С. Г. Тєлєтова, Т.Є. Оболенської, Н.С. Ільяшенко, Э.Н. Воронько, С.М. Іванченка $[3,5,6,8,11]$. А досвід діяльності процвітаючих освітніх установ наочно демонструють, що використання методів маркетингу в управлінні, є запорукою їх економічної ефективності в умовах ринку.

Визначення окремих питань, що не вирішені в обраній для дослідження проблемі. Аналіз наукових робіт вітчизняних та зарубіжних вчених свідчить про те, що більшість авторів не відокремлюють методи маркетингу освіти від класичного маркетингу [4-6]. В роботах, що присвячені відмінним атрибутам маркетингу освіти від класичного маркетингу зазначено, що «принципи маркетингу в сфері освіти аналогічні принципам традиційного маркетингу. Однак деякі з принципів мають більш важливе значення, ніж інші» [6]. Водночас аналіз робіт, що присвячені практичним аспектам маркетингу освітніх послуг, доводить, що рішення функціональних завдань маркетингу освітніх послуг потребує удосконаленні та розвитку спеціального інструментарію [7-9]. Звідси пропонується, використовуючи існуючу теоретичну базу i результати досліджень ефективного управління ВНЗ на практиці, визначити основні особливості впровадження маркетингових заходів в сфері освітніх послуг, на підставі яких в подальшому буде запропоновано цілісну маркетингову стратегію.

Метою написання даної статті $\epsilon$ визначення особливостей впровадження маркетингових заходів в сфері освітніх послуг.

Виклад основного матеріалу статті з обгрунтуванням отриманих наукових результатів. В Україні освітня система як сукупність соціальних інститутів, чиєю метою є освіта людини, сформувалася 3 радянських часів, а сама структура по сьогоднішній день залишилася незмінною. До елементів освітньої системи відносяться: початкова і середня школи, професійні училища, технікуми, вищі навчальні заклади, різні системи підвищення кваліфікації та перепідготовки кадрів та ін.

Верхнім рівнем освіти, наступним після середньої загальної або професійної освіти в трирівневій системі, є вища освіта, яка включає в себе сукупність систематизованих знань і практичних навичок, які дозволяють вирішувати теоретичні і практичні завдання 3 професійного профілю. На відміну від загальної освіти, як і в більшості розвинених країн світу, в Україні вища освіта не $\epsilon$ загальною та безкоштовною [3,5].

За період незалежності України вища школа зіткнулася 3 проблемами, які доцільно аналізувати в хронологічному порядку.

На початку 90-х років в Україні, в умовах інтенсивного розвитку бізнесу та змін в судово-правовій системі, не вистачало кваліфікованих економістів та юристів. Відповіддю на це стало відкриття зазначених спеціальностей в непрофільних вузах, незважаючи на слабку матеріальну базу і недостатнє забезпечення професорсько- 
викладацьким складом. Також в цей же період часу змінились основи правового регулювання трудових відносин державою. Це призвело до того, що більшість роботодавців стали вимагати від своїх працівників обов'язкової наявності диплому про вище освіту. В умовах попиту на вищу освіту почали з'являтися приватні ВНЗ та розширюватися заочна освіта. Як результат виникла гостра проблема якості підготовки фахівців.

3 2000-х років стала актуальною проблема стійкої тенденції до скорочення числа абітурієнтів. Так, наприклад, з 2011 року сукупність бюджетних і платних місць у ВН3 України дорівнюють кількості школярів, що закінчили середню школу [3]. В той же час останні 5 років все більший відсоток молоді їде за кордон здобувати вищу освіту, в тому числі з наміром залишитися там назавжди [3,5].

Необхідно відмітити, що накоплення проблеми відбувається в умовах не достатньо ефективного вирішення попередніх.

Існуючі в Україні проблеми вищої освіти накладають відбиток на мотивацію абітурієнта при виборі ВНЗ.

На сьогоднішній день існує думка, що в сучасних умовах, коли відбувається перехід від підготовки фахівця до утворення людини і формування особистості, необхідно впроваджувати нову освітню парадигму особистісно-орієнтованого навчання. Проте, можна стверджувати, що в Україні основним мотивом до підвищення власного освітнього рівня, $\epsilon$ прагнення до розвитку професійної компетентності і поліпшення свого соціального статусу [5].

Таким чином, щоб визначити особливості впровадження маркетингових заходів в сфері освітніх послуг, необхідно визначити ключові передумови формування стимулів і мотивів споживачів освітніх послуг, для кожного з яких в подальшому запропонувати власні заходи щодо залучення студентів.

Маркетинг освітніх послуг виник в надрах некомерційного маркетингу, який отримав розвиток в 1960-і роки в США. У 1970-80 pp. положення цієї теорії були розглянуті стосовно питань навчання дорослих та підвищення кваліфікації. У 1980 p німецькі вчені В. Загерс і Ф. Хеберлін запропонували першу комплексну концепцію освітнього маркетингу щодо виробничого підвищення кваліфікації. Маркетинг освіти вони віднесли до спеціального маркетингу послуг [4,5].

Суть маркетингу як філософії ринку виражається, перш за все в тому, що на перше місце ставляться запити споживача. Причому мова йде про конкретні цільові групи споживачів, про чітко окреслены сегменти ринку з властивими їм особливими потребами й можливостями щодо попиту на товари і послуги $[4,5]$. Особливо це ново і незвично для такої галузі вітчизняної економіки, як сфера освіти.

Головне завдання маркетингу освітніх послуг - максимізація соціального ефекту, який полягає в [5]: освіти;

- максимальному задоволенні соціально важливих потреб суспільства в сфері

- масовому охопленню та впливу на максимальну кількість членів суспільства;

- раціональному використанню обмежених суспільних ресурсів.

Ефективність застосування маркетингу освітніх послуг виражається в оцінці соціального ефекту (який, по суті, є результатом впливу на громадян і сприяє зміні соціальних пріоритетів) і економічного ефекту (заради якого здійснюється переважна більшість видів діяльності).

Процес впровадження маркетингових заходів в сфері освітніх послуг має свою специфіку в області практичного застосування. Стосовно основних принципів, методів 
та інструментів він тотожний процесу впровадження маркетингових заходів на будьякому ринку товарів або послуг

Більшість авторів зосереджує свою увагу на наступних особливостях маркетингу освітніх послуг. В [5,6] зазначено, що більшість характеристик освітньої послуги $€$ якісними, тобто такими, які неможливо оцінити кількісно. Однією з особливостей освітніх послуг є складність попередньої оцінки її ефективності. Особливості у виборі цільового сегменту полягають в тому, що на ринку освітніх послуг складно визначити, який саме сегмент $\epsilon$ цільовим. Адже часто однакові базові послуги можуть пропонуватися на різних сегментах ринку. Так, наприклад, послуги навчання за заочною формою можуть пропонуватися як випускникам шкіл, так і вже працюючим людям різного віку.

Першим етапом впровадження маркетингових заходів в сфері освітніх послуг $\epsilon$ виявлення найбільш популярних, а, отже, ефективних, джерел отримання інформації про ВН3 [5].

Джерелами інформації тут можуть служити [7,10,11]:

- профорієнтаційна робота, що проводиться викладачами ВНЗ в школах;

- реклама в газетах і журналах, на радіо і телебаченні, в соціальних мережах;

- довідкова література для абітурієнтів;

- контент офіційного сайту ВНЗ при самостійному пошуку ВНЗ;

- думка знайомих, друзів, рідних.

Як вже було зазначено, основним джерелом інформації є думка знайомих, друзів, рідних, далі офіційний сайт та реклама. Звідси можна визначити, що всупереч існуючій думці цільовою аудиторією виступають не тільки молоді люди у віці від 16 до 30 років, але їхні батьки, вік яких коливається в межах 40-60 років. У той же час споживачами освітніх послуг залишаються молоді люди. Теоретично вважається, що мотивація молодих споживачів освітніх послуг зазвичай сильно відрізняється від мотивації людей старшого віку [10,5].

Отже, першу особливість, яку необхідно враховувати при впровадженні маркетингових заходів в сфері освітніх послуг, можна сформулювати наступним чином: в більшості випадків особа, що приймає рішення про вибір ВНЗ для вступу, не $\epsilon$ споживачем освітньої послуги, але думка останнього (також в більшості випадків) $є$ значущою. Звідси, можна зробити висновок, що цільовою аудиторією виступає не тільки абітурієнт, але і його батьки, і мотиви, які спонукають до вступу, повинні задовольняти обох.

Далі при впровадженні маркетингових заходів в сфері освітніх послуг необхідно визначити фактори, що впливають на вибір абітурієнтів при вступі до ВНЗ, серед яких можна виділити [7,10,11]:

- поради батьків, друзів, знайомих;

- інформація, що отримана від представників ВНЗ (дні відкритих дверей та ін.);

- відвідування підготовчих курсів;

- реклама.

Для українських абітурієнтів основним мотивом для вибору ВНЗ та спеціальності $\epsilon$ порада батьків, друзів, знайомих та відвідування підготовчих курсів. Можна бачити парадоксальну ситуацію, коли високовитратні способи просування (реклама) виявляються неефективними [10,11]. Що стосується «днів відкритих дверей», то, як правило, їх відвідують цілеспрямовано з метою отримати додаткову інформацію і скласти власне враження про переваги ВНЗ. Високий ступінь довіри до інформаційних повідомлень, отриманих від незацікавлених осіб, обумовлений декількома причинами. 
По-перше, широко поширена думка, що престижний ВНЗ не потребує реклами в засобах масової інформації, по-друге, присутня оцінка особистості, що дає поради, якщо вона позитивна, то одержувач інформації не проігнорує іiі $[10,11]$.

Отже, друга особливість, яку необхідно враховувати при впровадженні маркетингових заходів в сфері освітніх послуг, полягає в тому, що традиційні способи реклами не тільки неефективні, але і знижують «цінність» ВНЗ в очах споживача.

Останнє, що пропонується визначити при впровадженні маркетингових заходів в сфері освітніх послуг - критерії вибору абітурієнтами ВНЗ. На практиці, серед найбільш значущих виділяють $[7,10,11]$ :

- місцезнаходження ВНЗ;

- можливість безкоштовного навчання;

- матеріально-технічна база, військова кафедра, гуртожитки;

- вартість навчання у ВНЗ на позабюджетному місці.

- місце ВНЗ в різних рейтингах;

В якості основних критеріїв для українських абітурієнтів виступає можливість отримання безкоштовної освіти $[10,11]$. Щодо рейтингів університетів, то вони для абітурієнта не мають головного значення. Відомо, що рейтинг університетів відображає інтегральну оцінку якості підготовки випускників, що визначається статистичними параметрами освітньої та науково-дослідної діяльності ВНЗ та якісними характеристиками, що відображають думку ключових референтних груп: роботодавців, представників академічних та наукових груп, а також студентів і випускників. На перше місце в більшості рейтингів університетів ставиться не якість освіти випускників, а наукові досягнення викладачів в частині цитованості в провідних міжнародних виданнях. Необхідно відзначити, що за часи Радянського Союзу та після, наука існувала не в університетах, а в Академії наук. Тому викладачам університетів, які багато років більшість часу присвячували освітній діяльності, а не фундаментальним науковим дослідженням, досить складно наздогнати своїх іноземних колег по цитованості. Необхідно відмітити, що абітурієнт при виборі місця навчання більше враховує не рейтинги, що розраховується на основі представлених ВНЗ даних, а ті фактори, що відповідають його особистим очікуванням та особливостям регіону [8].

Незважаючи на наявність заявлених критеріїв у споживачів, університет, який має можливість задовольнити вимоги споживача освітньої послуги, встановлює бар'єри для тих абітурієнтів, які з огляду на недостатній рівень знань, не зможуть в майбутньому отримати якісну освіту. Більшість ВНЗ надають освіту на конкурсній основі, це означає, що послуги будуть надані тільки тому споживачеві знання, вміння і навички якого, відповідають критеріям ВНЗ. Маючи власні критерії вибору ВНЗ, майбутній студент повинен відповідати вимогам, що пред'являються.

Звідси особливістю виступає те, що задовольняючи критеріям абітурієнта як майбутнього споживача освітніх послуг, ВНЗ може відмовити йому в їх наданні.

Таким чином, при впровадженні маркетингових заходів в сфері освітніх послуг необхідно враховувати, що цільова аудиторія ділиться на споживачів і осіб, що приймають рішення, реклама ВНЗ в газетах і журналах, на радіо і телебаченні неефективна, а попит на освітню послугу з боку абітурієнта, який відповідає вимогам ВН3, може бути не задоволений. Якщо враховувати кожну з зазначених особливостей окремо, то інструментів для ефективних маркетингових заходів - достатня кількість. Якщо ж розглядати їх в сукупності, то, в умовах перевищення пропозиції над попитом зниження вимог до абітурієнтів призведе до великого щорічного набору, але зменшить число позитивних інформаційних повідомлень про рівень підготовки у ВНЗ. Отримане 
протиріччя вимагає розробки і впровадження маркетингової стратегії, заходи якої задовольняли б кожній з розглянутих особливостей в комплексі.

Маркетингові заходи в сфері освітніх послуг повинні впроваджуватися не тільки на етапі профорієнтаційної роботи та приймальної кампанії, але і в процесі навчання.

На етапі профорієнтаційної роботи пропонується проводити презентації, дні відкритих дверей, підготовчі курси та розміщувати корисну для абітурієнта інформацію на офіційному сайті і контекстну рекламу в мережі Інтернет з посиланням на офіційний сайт.

Що стосується презентацій спеціальності, то іiі доцільно проводити на підприємствах тієї ж галузі або напряму знань, по якій ВНЗ пропонує навчання. Очевидно, що підприємство (установа) має бути досить великим і бажано, щоб на ньому успішно працювали випускники спеціальності. Ефективність таких презентацій полягає в тому, що батьки абітурієнтів матимуть можливість на основі прямих контактів 3 представниками ВНЗ отримати інформацію про «дні відкритих дверей» $\mathrm{i}$ підготовчі курси. Можливість встановлення особистих зав'язків підвищує лояльність цільової аудиторії.

Крім цього необхідна наявність офіційного сайту, який можна розглядати як інструмент інформування абітурієнтів про правила та механізм вступу до ВНЗ. Якщо вся необхідна інформація там представлена в доступній формі, то наступним кроком $\epsilon$ контекстна реклама, яка діє вибірково і відображається відвідувачам інтернет-сторінки, сфера інтересів яких потенційно збігається 3 тематикою рекламованого ВН3 спеціальності. Контекстна реклама, відкриваючи сторінку 3 більш детальною інформацією про ВНЗ, підвищує ймовірність відгуку цільової аудиторії.

Дні відкритих дверей та підготовчі курси є традиційними методами довузівської підготовки та профорієнтації. Відзначаючи їх значимість для забезпечення максимальної поінформованості абітурієнтів, пропонується агітацію за записом на них проводити не в школах, коледжах і технікумах, а в соціальних мережах в Інтернеті.

На етапі роботи приймальної кампанії інтерес для абітурієнтів, які не визначились 3 остаточним вибором ВНЗ, може скласти вичерпна і достовірна інформація на офіційному сайті, і презентація спеціальності у ВНЗ.

I останнє, що не має безпосереднього відношення до маркетингових заходів, але $є$ важливим мотивуючим фактором для абітурієнта - можливість подальшого працевлаштування за фахом. Якщо досягнуті результати навчання у вигляді можливості працевлаштування будуть залежати від прикладених зусиль студента, то це підвищить поінформованість про ВНЗ і кількість позитивних відгуків.

Висновки 3 даного дослідження. Таким чином, виявлені особливості впровадження маркетингових заходів в сфері освітніх послуг дозволили чітко сформулювати види маркетингових заходів, які потім будуть включені в маркетингову стратегію. Перевага даних заходів полягає в тому, що їх комплексне впровадження дозволить ефективно задовольняти запити споживачів ринку освітніх послуг, підвищуючи при цьому якість освіти.

Перспективи подальших досліджень. Університет в нових умовах господарювання змушений приймати нові риси. Задачі університету попереднього періоду відходять на задній план і головними стають питання адаптації до сучасних висококонкурентних умов функціонування, що передбачає розуміння необхідності постійної роботи зі створення сприятливих умов та посилення адаптаційних здібностей університетських комплексів. Виконання нових завдань неможливо без розробки стратегії розвитку університетів. Стратегічний розвиток університету передбачає 
підприємницьку активність шляхом введення до складу організаційної структури ряду відділів з маркетингу ринку освітніх послуг, ринку праці тощо, які не $\epsilon$ традиційними для вищої школи, але які дозволяють функціонувати університету, як об'єднанню, члени якого реалізують загальну стратегію розвитку.

\section{СПИСОК ВИКОРИСТАНИХ ДЖЕРЕЛ}

1. Вищі навчальні заклади [Электронный ресурс]: Державний комітет статистики України. - Режим доступа: http://www.ukrstat.gov.ua.

2. Розподіл постійного населення за окремими віковими групами. [Электронный ресурс]: Державний комітет статистики України. - Режим доступа: http://www.ukrstat.gov.ua.

3. Тєлєтова С. Г. Педагогічний маркетинг в умовах впровадження нового закону України про вищу освіту / С. Г. Тєлєтова // Маркетинг інновацій і інновації у маркетингу: зб. тез доповідей VIII-ї Міжнародної науково-практичної конференції. Суми : Папірус, 2014. - С. 184-186.

4. Kotler Philip Strategic Marketing for Educational Institutions / Philip Kotler, Karen F. A. Fox. - Prentice-Hall, Jan 1, 1985 - Education - 396 pages.

5. Оболенська Т.Є. Маркетинг освітніх послуг: вітчизняний та зарубіжний досвід / Т.Є. Оболенська. - К.: КНЕУ, 2001. - 208 с.

6. Ильяшенко Н. С. Отличительные особенности маркетинга образования от классического маркетинга / Н. С. Ильяшенко. - Маркетинг образовательных услуг: монография / под общ. ред. д-ра экон. наук, профессора О. В. Прокопенко. - Ruda Śląska : «Drukarnia i Studio Graficzne Omnidium», 2016. - C. 40-47

7. Карпіщенко М.Ю. Складання програми просування освітніх послуг вищих навчальних закладів на основі дослідження абітурієнтів Сумської області / М.Ю. Карпіщенко, В.В. Мілютіна // Вісник Ужгородського університету. Серія економіки. 2010. - №2. - C. 112-121.

8. Воронько, Э.Н. Совершенствование процесса управления региональным вузом на основе стратегии маркетинга / Э.Н. Воронько // Вестн. Полоцк. гос. ун-та. Cep. D. Экономические и юридические науки. - 2011. - № 13 - С. 34-38.

9. Гринькевич О.С. Статистические методы в решении функциональных задач маркетинга образовательных услуг / О.С. Гринькевич - Маркетинг образовательных услуг: монография / под общ. ред. д-ра экон. наук, профессора О. В. Прокопенко. Ruda Śląska : «Drukarnia i Studio Graficzne Omnidium», 2016. - C. 128-138

10. Пьянкова Е. А. Мотивация как фактор профессионального выбора в карьере молодых специалистов / Е. А. Пьянкова // Вестник развития науки и образования: научно-образовательный журнал. - 2010. - № 2. - С. 99-104.

11. Іванченко С. М. Соціально-психологічне дослідження проблеми якості вищої освіти / С. М. Іванченко, О. П. Щотка // Вісник Чернігівського національного педагогічного університету. Серія : Психологічні науки. - 2015. - Вип. 126. - С. 82-86. 